\title{
Mechanical evaluation of space closure loops in Orthodontics
}

\section{Eduardo Uggeri Rodrigues(a) \\ Hiroshi Maruo (a) \\ Odilon Guariza Filho(a) \\ Orlando Tanaka ${ }^{(a)}$ \\ Elisa Souza Camargo(a)}

(a) Department of Orthodontics, Pontifical Catholic University of Paraná, Curitiba, Paraná, Brazil.
Corresponding author:

Elisa Souza Camargo

Rua Fernando Simas, 327

Curitiba - PR - Brazil

CEP: 80430-190

E-mail: elisa.camargo@pucpr.br

Received for publication on May 12, 2010 Accepted for publication on Sep 19, 2010
Abstract: This study evaluated the mechanical performance of teardropshaped loops and teardrop-shaped loops with helix used in orthodontic space closure. Sixty retraction loops made with 0.019 " x 0.025 " stainless steel (SS) and beta-titanium (BT) wires were used. They were attached to a testing machine to measure the magnitudes of the sagittal force and the load-deflection ratio necessary for $1 \mathrm{~mm}, 2 \mathrm{~mm}$ and $3 \mathrm{~mm}$ activation. The results demonstrated that the BT alloy presented significantly smaller mean values $(\mathrm{p}<0.01)$ of sagittal force and load-deflection than the SS alloy. The loop with the highest mean value of sagittal force and load-deflection was the teardrop-shaped loop $(\mathrm{p}<0.01)$. Differences were observed in the mean values of sagittal force and load-deflection among activations, and the highest mean value was found in the activation of $3 \mathrm{~mm}$, while the smallest mean value was evident in the activation of $1 \mathrm{~mm}(\mathrm{p}<0.01)$. It could be concluded that the metallic alloy used and the presence of a helix in configuration of the loops may have a strong influence on the sagittal force produced and on the load-deflection ratio; the teardrop-shaped loops and teardrop-shaped loops with helix in BT presented the release of lighter forces; the teardrop-shaped loop in SS generated a high load-deflection ratio, providing high magnitudes of horizontal force during its deactivation.

Descriptors: Biomechanics; Orthodontic Space Closure; Stainless Steel.

\section{Introduction}

The use of loops for closing spaces in Orthodontics requires the professional to know the force systems offered by the orthodontic treatment mechanics, because if the mechanics associated with loops are used improperly, complications such as loss of anchorage, excessive verticalization of incisors, increase of overbite, dental mobility, root resorption, and increase in treatment time may result, with irreversible damage to the patient. ${ }^{1,2}$

Over the years, different loop configurations for closing spaces have been developed and are used in both continuous and segmented arches to provide dental movement. ${ }^{2}$

Therefore, during the selection of the best indicated model for each case, some variables such as loop design, thickness and properties of the wire used, type of movement desired and amount of force necessary, ${ }^{3}$ must be taken into consideration.

The efficacy of dental movement is directly related to the quantity 
of force used. Thus, Storey and Smith, ${ }^{4}$ Reitan ${ }^{5}$ and Krishnan and Davidovitch ${ }^{6}$ recommended the use of light forces, while Oppenheim ${ }^{7}$ and Burstone ${ }^{8}$ suggested the use of light forces and, whenever possible, continuous forces.

The constancy of a force generated by a certain loop basically depends on the load/deflection ratio (L/D), which must be the lowest possible. ${ }^{9}$ Loops with low L/D ratio release lighter, more constant and better controlled forces during deactivation because there is a smaller variation of force for each millimeter of activation. ${ }^{10}$ The loop configuration, incorporation of helices and the alteration of the orthodontic wire composition may diminish the L/D ratio. ${ }^{9,11}$

Thus, the aim of this study was to assess the mechanical behavior of the teardrop-shaped loop, varying its configuration and the type of alloy used.

\section{Material and Method}

The sample consisted of 60 test specimens, made by a single operator, using stainless steel (SS) 18/8 and beta-titanium (BT) wires (Dentsply GAC, New York, New York, USA), 0.019" x 0.025", divided as follows:

- 15 vertical SS loops, wider near the apex and closed at the base, similar in shape to a teardrop, ${ }^{12}$ called the teardrop loop.

- 15 vertical BT loops with the same configuration as SS.

- 15 vertical SS loops with the same configuration, but with the presence of a helix at the apex of the loop.

- 15 vertical BT loops with the same configuration, but with the presence of a helix at the apex of the loop.

The test specimens were made, measuring seven millimeters in height and three millimeters in the internal diameter of the helix. The two free extremities were $15 \mathrm{~mm}$ each (Figure 1), of which $5 \mathrm{~mm}$ of each extremity were used to fix the loops on the claws of the mechanical test machine (Emic, São José dos Pinhais, Paraná, Brazil), providing a symmetrical position.

Horizontal force $(\mathrm{HF})$ was recorded at the time of opening at $1.0 \mathrm{~mm}, 2.0 \mathrm{~mm}$ and $3.0 \mathrm{~mm}$ in grams-force (gf), and consequently the magnitude of the load/deflection ratio $(\mathrm{L} / \mathrm{D})(\mathrm{g} / \mathrm{mm})$ was also obtained. The values obtained for each group were compared at each millimeter of activation by comparing the factors of metal alloy and configuration.

The hypotheses were verified with ANOVA for 3 criteria, complete factorial model, and verification of normality was conducted with the KolmogorovSmirnov normality test at a level of significance of 0.05 . As normal distribution was not shown, the Kruskal-Wallis non-parametric test was applied at a level of significance of 0.05 .

\section{Results}

The mean values of $\mathrm{HF}$ and the L/D ratio, according to alloys and irrespective of loops and activations, are presented in Table 1. It was observed that the alloy with the highest mean HF value was SS, which was two times higher than the value for BT, and this difference was statistically significant $(\mathrm{p}<0.01)$.

When assessing the differences between the mean values of $\mathrm{HF}$ and $\mathrm{L} / \mathrm{D}$, according to loops and irrespective of alloys and activations (Table 2), it was observed that the teardrop-shaped loop showed the highest mean $\mathrm{HF}$ and L/D ratio when compared with the teardrop-shaped loop with helix $(\mathrm{p}<0.01)$.

When comparing the differences between the mean values of $\mathrm{HF}$ and $\mathrm{L} / \mathrm{D}$, according to activations and irrespective of alloys and loops (Table 3), it was observed that the activation with the highest HF mean was $3 \mathrm{~mm}$, while the activation with the lowest mean was $1 \mathrm{~mm}(\mathrm{p}<0.01)$.

In Tables 4 and 5 , the values obtained for the

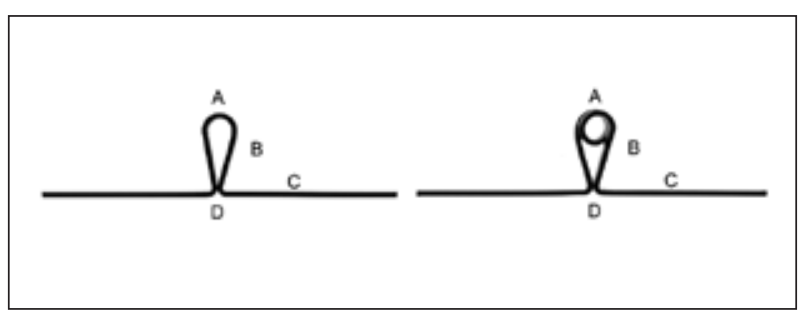

Figure 1 - Configuration of the teardrop-shaped and teardrop-shaped with helix loops and their respective dimensions: $\mathbf{A}$ (internal diameter of the loop and helix $-3.0 \mathrm{~mm}$ ), B (loop height - $7.0 \mathrm{~mm}$ ), C (free extremity - $15.0 \mathrm{~mm}$ ), D (two free extremities $-30.0 \mathrm{~mm}$ ). 
Table 1 - Descriptive statistics for the horizontal force $(\mathrm{g} f)$ and load/deflection $(\mathrm{g} / \mathrm{mm})$ variables, according to the alloys.

\begin{tabular}{|c|c|c|c|c|c|c|c|c|c|}
\hline \multirow{2}{*}{ Variable } & \multirow{2}{*}{ Alloys } & \multirow{2}{*}{$\mathrm{n}$} & \multirow{2}{*}{ Mean } & \multirow{2}{*}{ Median } & \multirow{2}{*}{$\begin{array}{l}\text { Standard } \\
\text { Deviation }\end{array}$} & \multirow{2}{*}{ C.V. (\%) } & \multirow{2}{*}{$\begin{array}{c}\text { Standard- } \\
\text { Error }\end{array}$} & \multicolumn{2}{|c|}{ Confidence interval $(95 \%$} \\
\hline & & & & & & & & $\mathrm{BL}$ & UL \\
\hline \multirow{2}{*}{$\begin{array}{l}\text { Horizontal } \\
\text { Force }\end{array}$} & SS & 90 & 772.01 & 771.44 & 295.26 & 38.25 & 31.12 & 710.07 & 833.94 \\
\hline & BT & 90 & 360.49 & 371.84 & 148.88 & 41.30 & 15.69 & 329.26 & 391.72 \\
\hline \multirow{2}{*}{$\begin{array}{c}\text { Load/ } \\
\text { Deflection }\end{array}$} & SS & 90 & 396.42 & 382.63 & 68.04 & 17.16 & 7.17 & 382.15 & 410.70 \\
\hline & BT & 90 & 181.57 & 185.89 & 23.34 & 12.86 & 2.46 & 176.67 & 186.47 \\
\hline
\end{tabular}

Source: Research data. Note: SS - stainless steel; BT - beta-titanium; C.V. - coefficient of variation; BL - bottom limit; UL - upper limit.

Table 2 - Descriptive statistics for the horizontal force $(\mathrm{gf})$ and load/deflection $(\mathrm{g} / \mathrm{mm})$ variables, according to the loops.

\begin{tabular}{|c|c|c|c|c|c|c|c|c|c|}
\hline \multirow{2}{*}{ Variable } & \multirow{2}{*}{ Loops } & \multirow{2}{*}{$N$} & \multirow{2}{*}{ Mean } & \multirow{2}{*}{ Median } & \multirow{2}{*}{$\begin{array}{l}\text { Standard } \\
\text { Deviation }\end{array}$} & \multirow{2}{*}{ C.V. (\%) } & \multirow{2}{*}{$\begin{array}{l}\text { Standard- } \\
\text { Error }\end{array}$} & \multicolumn{2}{|c|}{ Confidence interval (95\%) } \\
\hline & & & & & & & & $\mathrm{BL}$ & UL \\
\hline \multirow{2}{*}{$\begin{array}{c}\text { Horizontal } \\
\text { Force }\end{array}$} & Teardrop-shaped & 90 & 627.13 & 555.19 & 326.25 & 52.02 & 34.39 & 558.70 & 695.57 \\
\hline & Teardrop-shaped with helix & 90 & 505.36 & 424.81 & 284.67 & 56.33 & 30.01 & 445.65 & 565.08 \\
\hline \multirow{2}{*}{$\begin{array}{l}\text { Load/ } \\
\text { Deflection }\end{array}$} & Teardrop-shaped & 90 & 324.59 & 297.59 & 131.55 & 40.53 & 13.87 & 296.99 & 352.18 \\
\hline & Teardrop-shaped with helix & 90 & 253.41 & 257.12 & 92.99 & 36.69 & 9.80 & 233.90 & 272.91 \\
\hline
\end{tabular}

Source: Research data. Note: C.V. - coefficient of variation; BL - bottom limit; UL - upper limit.

Table 3 - Descriptive statistics for the horizontal force $(\mathrm{gf})$ and load/deflection $(\mathrm{g} / \mathrm{mm})$ variables, according to activations.

\begin{tabular}{|c|c|c|c|c|c|c|c|c|c|}
\hline \multirow{2}{*}{ Variable } & \multirow{2}{*}{ Activations } & \multirow{2}{*}{$\mathrm{n}$} & \multirow{2}{*}{ Mean } & \multirow{2}{*}{ Median } & \multirow{2}{*}{$\begin{array}{l}\text { Standard } \\
\text { Deviation }\end{array}$} & \multirow{2}{*}{ C.V. (\%) } & \multirow{2}{*}{$\begin{array}{c}\text { Standard- } \\
\text { Error }\end{array}$} & \multicolumn{2}{|c|}{ Confidence interval (95\%) } \\
\hline & & & & & & & & $\mathrm{BL}$ & UL \\
\hline \multirow{3}{*}{$\begin{array}{l}\text { Horizontal } \\
\text { Force }\end{array}$} & $1 \mathrm{~mm}$ & 60 & 307.81 & 278.27 & 139.02 & 45.16 & 17.95 & 271.92 & 343.71 \\
\hline & $2 \mathrm{~mm}$ & 60 & 573.21 & 532.41 & 227.92 & 39.76 & 29.42 & 514.36 & 632.05 \\
\hline & $3 \mathrm{~mm}$ & 60 & 817.72 & 776.93 & 300.92 & 36.80 & 38.85 & 740.03 & 895.42 \\
\hline \multirow{3}{*}{$\begin{array}{l}\text { Load/ } \\
\text { Deflection }\end{array}$} & $1 \mathrm{~mm}$ & 60 & 307.81 & 278.27 & 139.02 & 45.16 & 17.95 & 271.92 & 343.71 \\
\hline & $2 \mathrm{~mm}$ & 60 & 286.60 & 266.20 & 113.96 & 39.76 & 14.71 & 257.18 & 316.03 \\
\hline & $3 \mathrm{~mm}$ & 60 & 272.57 & 258.98 & 100.31 & 36.80 & 12.95 & 246.68 & 298.47 \\
\hline
\end{tabular}

Source: Research data. Note: C.V. - coefficient of variation; BL - bottom limit; UL - upper limit.

variables $\mathrm{HF}$ and $\mathrm{L} / \mathrm{D}$, according to the alloys, loops and activations can be seen.

\section{Discussion}

From the results obtained, it was observed that the horizontal force (HF) and load/deflection ratio (L/D) produced were strongly influenced by the metal alloy factor (Tables 4 and 5), with stainless steel (SS) showing higher magnitudes than beta-titanium (BT). It was also observed that, for the two types of alloys, the higher the activation amplitude, the higher were the HF and L/D ratio released. This is in agreement with Faulkner et al., ${ }^{13}$ when assessing vertical loops. Therefore, a loop made of an alloy with a low modulus of elasticity, such as beta-titanium, would have a lower load/deflection ratio than a loop made of stainless stee ${ }^{14}$ with the same configuration.

The incorporation of helices is an important factor to take into consideration. This is associated with the longer wire in the inter-bracket space, which promotes both increase in activation amplitude of the loop and reduction of the amount of HF produced. ${ }^{11,13,15,16,17}$

Therefore, it was also found that the HF and $\mathrm{L} / \mathrm{D}$ ratio released by the loops made of SS and BT 
Table 4 - Descriptive statistics for the horizontal force (gf) variable, according to the alloys, loops and activations.

\begin{tabular}{|c|c|c|c|c|c|c|c|c|}
\hline \multirow{2}{*}{$\begin{array}{c}\text { Alloy } x \text { loop } x \\
\text { activation }\end{array}$} & \multirow{2}{*}{$n$} & \multirow{2}{*}{ Mean } & \multirow{2}{*}{ Median } & \multirow{2}{*}{$\begin{array}{l}\text { Standard } \\
\text { Deviation }\end{array}$} & \multirow{2}{*}{ C.V. (\%) } & \multirow{2}{*}{$\begin{array}{l}\text { Standard- } \\
\text { Error }\end{array}$} & \multicolumn{2}{|c|}{ Confidence interval (95\%) } \\
\hline & & & & & & & $\mathrm{BL}$ & UL \\
\hline $\mathrm{SS} \times \mathrm{D} \times 1 \mathrm{~mm}$ & 15 & 511.01 & 508.96 & 32.50 & 6.36 & 8.39 & 493.05 & 528.96 \\
\hline $\mathrm{SS} \times \mathrm{D} \times 2 \mathrm{~mm}$ & 15 & 882.17 & 874.53 & 55.64 & 6.31 & 14.37 & 851.43 & 912.91 \\
\hline $\mathrm{SS} \times \mathrm{D} \times 3 \mathrm{~mm}$ & 15 & $1,188.08$ & $1,187.74$ & 60.33 & 5.08 & 15.58 & $1,154.75$ & $1,221.42$ \\
\hline $\mathrm{SS} \times \mathrm{DS} \times 1 \mathrm{~mm}$ & 15 & 349.07 & 343.21 & 24.27 & 6.95 & 6.27 & 335.66 & 362.48 \\
\hline $\mathrm{SS} \times \mathrm{DS} \times 2 \mathrm{~mm}$ & 15 & 684.71 & 675.94 & 37.66 & 5.50 & 9.72 & 663.90 & 705.52 \\
\hline $\mathrm{SS} \times \mathrm{DS} \times 3 \mathrm{~mm}$ & 15 & $1,017.00$ & 974.06 & 93.90 & 9.23 & 24.24 & 965.12 & $1,068.88$ \\
\hline $\mathrm{BT} \times \mathrm{D} \times 1 \mathrm{~mm}$ & 15 & 208.07 & 207.37 & 12.47 & 5.99 & 3.22 & 201.18 & 214.96 \\
\hline $\mathrm{BT} \times \mathrm{D} \times 2 \mathrm{~mm}$ & 15 & 401.11 & 404.58 & 15.09 & 3.76 & 3.90 & 392.77 & 409.45 \\
\hline $\mathrm{BT} \times \mathrm{D} \times 3 \mathrm{~mm}$ & 15 & 572.36 & 566.77 & 32.79 & 5.73 & 8.47 & 554.24 & 590.48 \\
\hline BT $\times$ DS $\times 1 \mathrm{~mm}$ & 15 & 163.10 & 158.07 & 22.09 & 13.54 & 5.70 & 150.90 & 175.31 \\
\hline $\mathrm{BT} \times \mathrm{DS} \times 2 \mathrm{~mm}$ & 15 & 324.83 & 323.35 & 27.22 & 8.38 & 7.03 & 309.79 & 339.87 \\
\hline $\mathrm{BT} \times \mathrm{DS} \times 3 \mathrm{~mm}$ & 15 & 493.45 & 487.26 & 37.66 & 7.63 & 9.72 & 472.65 & 514.26 \\
\hline
\end{tabular}

Source: Research data. Note: SS - stainless steel; BT - beta-titanium; D - teardrop-shaped; DS - teardrop-shaped with helix; C.V. - coefficient of variation; BL - bottom limit; UL - upper limit.

Table 5 - Descriptive statistics for the load/deflection $(\mathrm{g} / \mathrm{mm})$ variable, according to the alloys, loops and activations.

\begin{tabular}{|c|c|c|c|c|c|c|c|c|}
\hline \multirow{2}{*}{$\begin{array}{c}\text { Alloy } \mathrm{x} \text { loop } \mathrm{x} \\
\text { activation }\end{array}$} & \multirow{2}{*}{$\mathrm{n}$} & \multirow{2}{*}{ Mean } & \multirow{2}{*}{ Median } & \multirow{2}{*}{$\begin{array}{l}\text { Standard } \\
\text { Deviation }\end{array}$} & \multirow{2}{*}{ C.V. (\%) } & \multirow{2}{*}{$\begin{array}{c}\text { Standard- } \\
\text { Error }\end{array}$} & \multicolumn{2}{|c|}{ Confidence interval (95\%) } \\
\hline & & & & & & & $\mathrm{BL}$ & UL \\
\hline $\mathrm{SS} \times \mathrm{D} \times 1 \mathrm{~mm}$ & 15 & 511.01 & 508.96 & 32.50 & 6.36 & 8.39 & 493.05 & 528.96 \\
\hline $\mathrm{SS} \times \mathrm{D} \times 2 \mathrm{~mm}$ & 15 & 441.08 & 437.26 & 27.82 & 6.31 & 7.18 & 425.71 & 456.46 \\
\hline $\mathrm{SS} \times \mathrm{D} \times 3 \mathrm{~mm}$ & 15 & 396.03 & 395.91 & 20.11 & 5.08 & 5.19 & 384.92 & 407.14 \\
\hline $\mathrm{SS} \times \mathrm{DS} \times 1 \mathrm{~mm}$ & 15 & 349.07 & 343.21 & 24.27 & 6.95 & 6.27 & 335.66 & 362.48 \\
\hline $\mathrm{SS} \times \mathrm{DS} \times 2 \mathrm{~mm}$ & 15 & 342.36 & 337.97 & 18.83 & 5.50 & 4.86 & 331.95 & 352.76 \\
\hline $\mathrm{SS} \times \mathrm{DS} \times 3 \mathrm{~mm}$ & 15 & 339.00 & 324.69 & 31.30 & 9.23 & 8.08 & 321.71 & 356.29 \\
\hline $\mathrm{BT} \times \mathrm{D} \times 1 \mathrm{~mm}$ & 15 & 208.07 & 207.37 & 12.47 & 5.99 & 3.22 & 201.18 & 214.96 \\
\hline $\mathrm{BT} \times \mathrm{D} \times 2 \mathrm{~mm}$ & 15 & 200.56 & 202.29 & 7.55 & 3.76 & 1.95 & 196.39 & 204.73 \\
\hline $\mathrm{BT} \times \mathrm{D} \times 3 \mathrm{~mm}$ & 15 & 190.79 & 188.92 & 10.93 & 5.73 & 2.82 & 184.75 & 196.83 \\
\hline BT $x$ DS $x 1 \mathrm{~mm}$ & 15 & 163.10 & 158.07 & 22.09 & 13.54 & 5.70 & 150.90 & 175.31 \\
\hline BT $\times$ DS $\times 2 \mathrm{~mm}$ & 15 & 162.41 & 161.67 & 13.61 & 8.38 & 3.51 & 154.89 & 169.93 \\
\hline BT $\times$ DS $\times 3 \mathrm{~mm}$ & 15 & 164.48 & 162.42 & 12.55 & 7.63 & 3.24 & 157.55 & 171.42 \\
\hline
\end{tabular}

Source: Research data. Note: SS - stainless steel; BT - beta-titanium; D - teardrop-shaped; DS - teardrop-shaped with helix; C.V. - coefficient of variation; BL - bottom limit; UL - upper limit.

were greatly influenced by the presence of the helix, resulting in reduction of the mean magnitude of HF by approximately $21 \%$ for the SS teardrop-shaped loop, and by $17 \%$ for the BT teardrop-shaped loop.

Increasing intensities of $\mathrm{HF}$ and $\mathrm{L} / \mathrm{D}$ ratio were produced in the following order:

1. BT loops with helix;
2. BT loops without helix;

3. SS loops with helix;

4. SS loops without helix.

In the study conducted by Thiesen et al. ${ }^{18}$ higher force magnitudes were also found in SS loops without helix, as compared to SS loops with helix. When assessing the forces released by the SS teardrop- 
shaped loops without helix separately, levels close to those found by Shimizu et al. ${ }^{19}$ were observed in the same type of loop. However, Neto, Mucha and Chevitarese ${ }^{17}$ obtained higher levels of force in comparison to those obtained in this study, probably due to the smaller dimensions: that is, $6 \mathrm{~mm}$ in height and $3 \mathrm{~mm}$ in width.

Thiesen et al. ${ }^{18}$ tested SS teardrop-shaped loops with helix, measuring $8 \mathrm{~mm}$ in height and $4 \mathrm{~mm}$ in width, and they obtained forces of lower magnitude as compared to those obtained in this study: that is, $212 \mathrm{gf}, 446 \mathrm{gf}$ and $660 \mathrm{gf}$ for $1 \mathrm{~mm}, 2 \mathrm{~mm}$ and $3 \mathrm{~mm}$ activations, respectively. Substantial differences among the results are observed, indicating marked variations of force when the loop dimensions are altered. Thiesen et al. ${ }^{18}$ when quantifying the L/D ratio of teardrop-shaped loops with and without helix, found lower magnitude values and higher constancy for the loops with helices. This is in agreement with Burstone and Koenig, ${ }^{20}$ who affirmed that one of the ways to achieve a low L/D ratio would be to incorporate more wire into the apical portion, especially in the helical shapes. The L/D ratio values obtained by Thiesen et al. ${ }^{18}$ were of lower magnitude as compared to those obtained in this study.

When assessing teardrop-shaped loops, with and without helix, made of BT, Thiesen ${ }^{21}$ found very close $\mathrm{L} / \mathrm{D}$ ratio values among the activations, but of lower intensity than the values for the SS loops. The higher L/D ratio values in this study accompany the HF results that were also higher, as were also the results of Thiesen, ${ }^{21}$ probably due to the configuration of the specimen tested in this study having smaller dimensions.

The results of this study showed that the majority of the loops tested produced high forces. When comparing the values of the forces obtained (values are presented in grams-force, because clinically there

\section{References}

1. Begg PR. Differential force in orthodontic treatment. Am J Orthod Dentofacial Orthop. 1956 Jul;42(7):481-510.

2. Thiesen G, Rego MVNN, Menezes LM, Shimizu RH. [Using different T-loops configurations to obtain optimized force is bilateral presence of loops in the arch to retract the anterior segment), with excellent $\mathrm{HF}$ values recommended by Jarabak and Fizzel, ${ }^{22}$ the $1 \mathrm{~mm}$ activated $\mathrm{BT}$ teardrop-shaped loops produced favorable levels of HF (416 gf) to move mandibular incisors and canines. An adequate amount of force to move maxillary incisors was obtained with the activation of $1 \mathrm{~mm}$ BT loops with helix (326 gf). For the mass movement of maxillary incisors, the $2 \mathrm{~mm}$ activated BT loops with helix generated compatible levels of HF (649 gf). When the teardrop-shaped loops and the teardrop-shaped loops with helix are made of SS wire, they do not provide adequate HF levels to move anterior teeth, irrespective of their activation.

Lighter force levels are preferable for dental movement. $5,6,23,24,25$ In this study, the incorporation of spirals and the use of BT alloys provided lower force levels. However, it is the professional's responsibility to select the loop, compare the configurations, metal alloys and wire thicknesses that are available, and to use the one that presents the best characteristics for the particular case.

\section{Conclusions}

1. The beta-titanium loops produced lower amounts of horizontal force and load/deflection ratio than the stainless steel loops.

2. The teardrop-shaped loops with helix generated lower amounts of horizontal force and load/deflection ratio than the teardrop-shaped loops.

3. The stainless steel loops generated high load/deflection proportions, and consequently provided higher levels of horizontal force during their deactivation.

\section{Acknowledgements}

The authors thank Prof. Dr. Sérgio Aparecido Ignácio for performing the Statistical Analysis.

systems]. Rev Dent Press Ortodon Ortop Facial. 2006 SepOct;11(5):57-77. Portuguese

3. Lindauer SJ, Britto AD. Biological response to biomechanical signals: Orthodontic mechanics to control tooth movement. Semin Orthod. 2000 Sep;6(3):145-54. 
4. Storey E, Smith R. Force in orthodontics and its relation to tooth movement. Aust J Dent. 1952 Feb;56(1):11-8.

5. Reitan K. Some factors determining the evaluation of forces in orthodontics. Am J Orthod Dentofacial Orthop. 1957 Jan;43(1):32-45.

6. Krishnan V, Davidovitch Z. Cellular, molecular, and tissuelevel reactions to orthodontic force. Am J Orthod Dentofacial Orthop. 2006 Apr;129(4):469.e1-32.

7. Oppenheim A. A Possibility for physiologic orthodontic movement. Am J Orthod Oral Surg. 1944 Jun;30(6):277-328.

8. Burstone CJ. The mechanics of the segmented arch techniques. Angle Orthod. 1966 Apr;36(2):99-120.

9. Staggers JA, Germane N. Clinical considerations in the use of retraction mechanics. J Clin Orthod. 1991 Jun;15(8):565-9.

10. Gjessing P. Biomechanical design and clinical evaluation of a new canine-retraction spring. Am J Orthod Dentofacial Orthop. 1985 May;87(5):353-62.

11. Mayoral J, Mayoral G. Técnica ortodoncia con fuerzas ligeras. Barcelona: Labor; 1976. 793 p.

12. Tweed CH. Clinical Orthodontics. $3^{\text {rd }}$ ed. Saint Louis: Mosby; 1966. 946 p.

13. Faulkner MG, Lipsett AW, El-Rayes K, Haberstock DL. On the use of vertical loops in retraction systems. Am J Orthod Dentofacial Orthop. 1991 Apr;99(4):328-36.

14. Schillai G, Lehmann KM. [Study about force and load deflection relationship on activation of different closing loops]. Fortschr Kieferorthop. 1989 May;50(3):172-8. German.

15. Burstone CJ. The segmented arch approach to space closure. Am J Orthod Dentofacial Orthop. 1982 Nov;82(5):361-78.

16. Coimbra MER, Penedo ND, Gouvêa JP, Elias CN, Araújo MTS, Coelho PG. Mechanical testing and finite element analy- sis of orthodontic teardrop loop. Am J Orthod Dentofacial Orthop. 2008 Feb;133(2):188.e9-13.

17. Scalza Neto P, Mucha JN, Chevitarese O. [Spring of the space closure in orthodontics in tearlike form: traction performance]. Rev Bras Odontol. 1985 Nov-Dec;42(6):22-9. Portuguese.

18. Thiesen G, Rego MVNN, Menezes LM, Shimizu RH. [Biomechanical evaluation of different orthodontic space closure loops manufactured with stainless steel]. Rev Assoc Paul Espec Ortodon Ortop Facial. 2004 Apr-May-Jun;2(2):77-92. Portuguese.

19. Shimizu RH, Sakima T, Santos-Pinto A, Spinelli D, Shimizu IA. [Mechanical characteristics of the Bull loop modified during the orthodontic space closure]. Rev Dent Press Ortodon Ortop Facial. 2002 Mar-Apr;7(2):13-24. Portuguese.

20. Burstone CJ, Koenig HA. Optimizing anterior and canine retraction. Am J Orthod. 1976 Jul;70(1):1-19.

21. Thiesen G. Análise dos sistemas de forças produzidos por diferentes alças ortodônticas para fechamento de espaços [tese]. [Porto Alegre]: Pontifícia Universidade Católica do Rio Grande do Sul; 2003. 208 p.

22. Jarabak JR, Fizzel JA. Aparatologia del arco de canto com alambres delgados. Buenos Aires: Mundi; 1975.612 p.

23. Burstone CJ. Rationale of the segmented arch. Am J Orthod. 1962 Nov;48(11):805-22.

24. Quinn RS, Yoshikawa DK. A reassessment of force magnitude in orthodontics. Am J Orthod. 1985 Sep;88(3):252-60.

25. Sarikaya S, Haydar B, Ciger S, Ariyürek M. Changes in alveolar bone thickness due to retraction of anterior teeth. Am J Orthod Dentofacial Orthop. 2002 Jul;122(1):15-26. 